\title{
Chemical constituents of volatile oil from Pyrolae herba and antiproliferative activity against SW1353 human chondrosarcoma cells
}

\author{
LIANGLIANG CAI*, HONGZHI YE*, XIHAI LI, YANPING LIN, FANGRONG YU, \\ JIASHOU CHEN, HUITING LI and XIANXIANG LIU
}

Academy of Integrative Medicine, Fujian University of Traditional Chinese Medicine, Fuzhou, Fujian 350108, P.R. China

Received November 6, 2012; Accepted January 11, 2013

DOI: $10.3892 /$ ijo.2013.1816

\begin{abstract}
The objective of the present study was to identify chemical constituents of volatile oil from Pyrolae herba (PHVO) and evaluate the antiproliferative activity of PHVO against SW1353 human chondrosarcoma cells. The volatile oil from Pyrolae herba was prepared by hydrodistillation and characterized by gas chromatography-mass spectroscopy (GC-MS). A total of 12 components in PHVO were identified representing $81.62 \%$ of the total integrated chromatographic peaks. The major compounds were found to be n-hexadecanoic acid (29.29\%), cedrol (17.08\%), 6,10,14-trimethyl-2-pentadecanone $(9.59 \%)$ and cis-9-octadecadienoic acid (8.23\%). The antiproliferative activity of PHVO against SW1353 cells was investigated using MTT assay, flow cytometry and western blot analysis. Our results demonstrated that PHVO inhibited SW1353 cell viability in a dose- and time-dependent manner. Furthermore, PHVO treatment decreased the number of cells entering the $S$ phase and caused a reduction in the expression of cyclin D1, cyclin-dependent kinase (CDK)4 and CDK6, whereas it caused an increase in the expression of $\mathrm{p} 21$. PHVO demonstrated potent antitumor activity against SW1353 cells, suggesting its potential use as a therapeutic agent in the treatment of chondrosarcoma.
\end{abstract}

Correspondence to: Professor Xianxiang Liu, Academy of Integrative Medicine, Fujian University of Traditional Chinese Medicine, 1 Huatuo Road, Minhou Shangjie, Fuzhou, Fujian 350108, P.R. China

E-mail: liuxianxiang@163.com

*Contributed equally

Abbreviations: PHVO, volatile oil from Pyrolae herba; GC-MS, gas chromatography-mass spectroscopy; MTT, 3-(4,5-dimethythiazol-2yl)-2,5-diphenyltetrazolium bromide; DMSO, dimethyl sulfoxide

Key words: Pyrolae herba, volatile oil, chemical constituent, gas chromatography-mass spectroscopy, antiproliferative activity

\section{Introduction}

Chondrosarcoma is the most common primary malignant bone tumor in children and adolescents, comprising almost $60 \%$ of all bone sarcomas $(1,2)$. To date, the main treatments for patients with osteosarcoma are surgical resection and chemotherapy (3). However, despite advances in chemotherapy and surgery, the survival rate for osteosarcoma has reached a plateau and $40 \%$ of osteosarcoma patients eventually succumb to the disease; thus, there is an urgent need for the development of novel therapeutic agents (4).

Over the past few years, natural products have attracted extensive attention due to their relatively few side-effects and have been used in clinical practice for thousands of years as important alternative remedies for a variety of diseases (5-7). Moreover, natural products are an attractive source of new therapeutic candidate compounds, which make an enormous contribution to drug discovery today (8). An analysis of the number of chemotherapeutic agents and their sources indicates that over $60 \%$ of approved drugs are derived from natural compounds (9). Several plant-derived compounds are currently successfully employed in disease treatment. For instance, arteannuin, which was isolated from Artemisia annua, has been used for the treatment of malaria and the vinca alkaloid isolated from the periwinkle Catharanthus roseus has been used for the treatment of cancer $(10,11)$. Volatile oils are a type of secondary plant metabolite, and have been shown to exhibit antioxidant and antibacterial activities $(12,13)$.

Pyrolae herba listed in Chinese Pharmacopoeia is commonly used in traditional Chinese medicine for the treatment of cancer, hypertension, coronary heart disease and various inflammatory diseases, including rheumatoid arthritis and arthralgia. Pyrolae herba functions by expelling wind and removing dampness, and promoting blood circulation for the regulation of menstruation and the relief of pain $(14,15)$. In modern pharmacological studies, the active components of Pyrolae herba such as chimaphilin, ursolic acid and hyperoside had previously been shown to possess anti-inflammatory, antioxidant and antibacterial properties (16-21). Recent studies have suggested that ursolic acid inhibits cell proliferation and downregulates the expression of anti-apoptotic and metastatic gene products, potentiating antitumor activity (22-25). 
However, the chemical constituents and antitumor activity of volatile oil from Pryrolae herba have not yet been reported.

In this study, volatile oil from Pyrolae herba (PHVO) was obtained by hydrodistillation and identified by gas chromatography-mass spectrometry (GC-MS). To further investigate the antiproliferative activity of PHVO against SW1353 cells, MTT assay was used to evaluate its inhibitory activity. Moreover, cell cycle distribution and protein expression levels of cyclin D1, cyclin-dependent kinase (CDK)4, CDK6 and p21 were determined by flow cytometry and western blot analysis, respectively.

\section{Materials and methods}

Materials and reagents. Pyrolae herba was purchased from Jiangxi Herb Co.,Ltd., Nanchang, Jiangxi, China (Chinese FDA approval no. 1202001). Fetal bovine serum (FBS), Dulbecco's modified Eagle's medium (DMEM) and trypsin-EDTA were purchased from HyClone (Logan, UT, USA). MTT was obtained from Sigma-Aldrich (St. Louis, MO, USA). The cycle test kit was purchased from Becton-Dickinson (San Jose, CA, USA). The total protein extraction kit was purchased from Nanjing KeyGen Biotech (Nanjing, China). Polyvinylidene fluoride (PVDF) membrane was purchased from Millipore (Lincoln Park, NJ, USA). Rabbit anti-rat cyclin D1, CDK4, CDK6 and p21, and $\beta$-actin HRP secondary goat anti-rabbit antibodies were purchased from Santa Cruz Biotechnology Inc. (Santa Cruz, CA, USA).

Extraction of essential oil. A total of $300 \mathrm{~g}$ of Pyrolae herba was placed in a 5-1 round-bottom flask with 31 deionized water. The material was soaked for approximately $2 \mathrm{~h}$ before it was subjected to hydrodistillation, then Pyrolae herba were distilled for $6 \mathrm{~h}$ to collect volatile oil, according to the method recommended by Chinese Pharmacopoeia (26). The essential oil was dried over anhydrous sodium sulfate and stored at $-20^{\circ} \mathrm{C}$ in the dark.

GC-MS analysis. GC-MS analysis was performed on an Agilent 6890N Network GC System, fitted with a HP-5MS capillary column $[30 \mathrm{~m}$ x $0.25 \mathrm{~mm}$ inner diameter (i.d.) $\mathrm{x}$ $0.25 \mu \mathrm{m}$ film thickness; maximum temperature, $350^{\circ} \mathrm{C}$ ], coupled to an Agilent 5975 inert XL Mass Selective Detector. Helium was used as the carrier gas with a flow rate of $1.0 \mathrm{ml} /$ min and the injector was set at $250^{\circ} \mathrm{C}$. The GC oven initial temperature was $50^{\circ} \mathrm{C}$ for $3 \mathrm{~min}$, then programmed to $160^{\circ} \mathrm{C}$ at $1.5^{\circ} \mathrm{C} / \mathrm{min}$ and increased to 280 at $3^{\circ} \mathrm{C} / \mathrm{min}$, finally holding at $280^{\circ} \mathrm{C}$ for $40 \mathrm{~min}$. The ion source temperature was $230^{\circ} \mathrm{C}$. MS scanning was carried out at $70 \mathrm{eV}$ over a mass range of 30-500 amu. Samples were injected $(1 \mu \mathrm{l})$ with a split mode ratio of 50:1. Compounds were identified by comparing their spectral data and retention time with data from NIST Mass Spectral Library.

Cell culture. The SW1353 human chondrosarcoma cell line was obtained from the Institute of Biochemistry and Cell Biology, Chinese Academy of Sciences (Shanghai, China). SW1353 cells were grown in DMEM containing $10 \%(\mathrm{v} / \mathrm{v})$ FBS, and $100 \mathrm{U} / \mathrm{ml}$ penicillin and $100 \mu \mathrm{g} / \mathrm{ml}$ streptomycin. Cells were grown in a $37^{\circ} \mathrm{C}$ incubator supplied with $5 \% \mathrm{CO}_{2}$.
Measurement of cell viability. Cell viability was determined by MTT assay. SW1353 cells were seeded in 96-well plates at a density of $1 \times 10^{4}$ cells/well in $0.1 \mathrm{ml}$ medium. The cells were treated with various concentrations of PHVO for $48 \mathrm{~h}$ or $100 \mu \mathrm{g} / \mathrm{ml}$ of PHVO for different periods of time. The medium was then removed and $20 \mu \mathrm{l}$ of $0.5 \%$ MTT solution were added to each well followed by incubation for $4 \mathrm{~h}$ at $37^{\circ} \mathrm{C}$. The purple-blue MTT formazan precipitate was dissolved in $100 \mu 1$ DMSO. The absorbance of each well was determined at $490 \mathrm{~nm}$ using an ELISA reader (BioTek, Model ELX800, Winnoski, VT, USA).

Flow cytometry detection of cell cycle. To determine the effect of PHVO on the cell cycle distribution, SW1353 cells were treated with various concentrations $(0,50,100,150 \mu \mathrm{g} / \mathrm{ml})$ of PHVO for $48 \mathrm{~h}$. The cells were harvested and washed with PBS. The cell concentration was adjusted to $1 \times 10^{6}$ cells $/ \mathrm{ml}$ following centrifugation. Solutions A, B and C were added according to the manufacturer's instructions. DNA content of the cells was measured by FACSCalibur (Becton-Dickinson) flow cytometry system and analyzed using Modfit LT version 3.0 (Verity Software House, Topsham, ME, USA).

Western blot analysis. SW1353 cells were seeded in culture flasks and treated with or without PHVO for $24 \mathrm{~h}$ at $37^{\circ} \mathrm{C}$. Cells were scraped from the culture, washed twice with PBS and then suspended in $30 \mu 1$ western blot lysis buffer. The protein concentration was then determined using the bicinchoninic acid (BCA) protein assay (Beyotime Biotechnology, Haimen, China). Samples were loaded with $20 \mu \mathrm{g}$ of protein and separated by electrophoresis on $12 \%$ SDS-polyacrylamide gels. Following electrophoresis, the protein blots were transferred onto a PVDF membrane. The membrane was blocked with 5\% skimmed milk in TBST solution and incubated overnight with primary antibodies at $4^{\circ} \mathrm{C}$. The membranes were then washed in TBST and exposed to secondary antibodies. Finally, the bands were quantified by scanning densitometry (170-8070; Molecular Imager ChemiDoc XRS System, Bio-Rad, Hercules, CA, USA).

Statistical analysis. All data are the means of three determinations and the data were analyzed using the SPSS 16.0 package. Student's t-tests and one-way ANOVA test were used to compare the differences among groups and P-values $<0.05$ were considered to indicate statistically significant differences.

\section{Results}

GC-MS analysis of the oil samples. The results of GC-MS analyses are listed in Table I. GC-MS analysis of the oil samples revealed the presence of 16 different components, 12 of which were listed (Table I), representing $81.62 \%$ of the total oil composition from Pyrolae herba. n-Hexadecanoic acid $(29.29 \%)$ was the main component of the oil, followed by cedrol (17.08\%), 6,10,14-trimethyl-2-pentadecanone $(9.59 \%)$ and cis-9-octadecadienoic acid (8.23\%).

PHVO inhibits the proliferation of SW1353 cells. In order to investigate the effect of PHVO on SW1353 cells, we first observed the cell density by phase-contrast microscopy. As 
Table I. Characteristics of the components of volatile oil from Pyrolae herba as shown by GC-MS analysis.

\begin{tabular}{clccc}
\hline Peak no. & \multicolumn{1}{c}{ Component } & RT (min) & RI & Peak area (\%) \\
\hline 1 & 4-Hexyl-2,5-dihydro-2,5-dioxo-3-furanacetic acid & 23.684 & 1490 & 1.26 \\
2 & Cedrol & 27.133 & 1580 & 17.08 \\
3 & 1,6-Dimethyl-4-isopropylnaphthalene & 29.187 & 1622 & 1.47 \\
4 & Tetradecanoic acid & 31.439 & 1712 & 2.35 \\
5 & 6,10,14-Trimethyl-2-pentadecanone & 33.67 & 1781 & 9.59 \\
6 & Di-iso-butyl phthalate & 34.308 & 1807 & 2.25 \\
7 & Isophytol & 36.595 & 1843 & 1.27 \\
8 & n-Hexadecanoic acid & 37.049 & 1862 & 29.79 \\
9 & Hexadecanoic acid ethyl ester & 38.047 & 1889 & 1.90 \\
10 & Phytol & 41.865 & 1914 & 4.72 \\
11 & Cis-9-octadecadienoic acid & 42.715 & 1927 & 8.23 \\
12 & 11-Decyl-tricosane & 55.584 & 2101 & 1.71 \\
\hline
\end{tabular}

RT, retention time; RI, retention index.
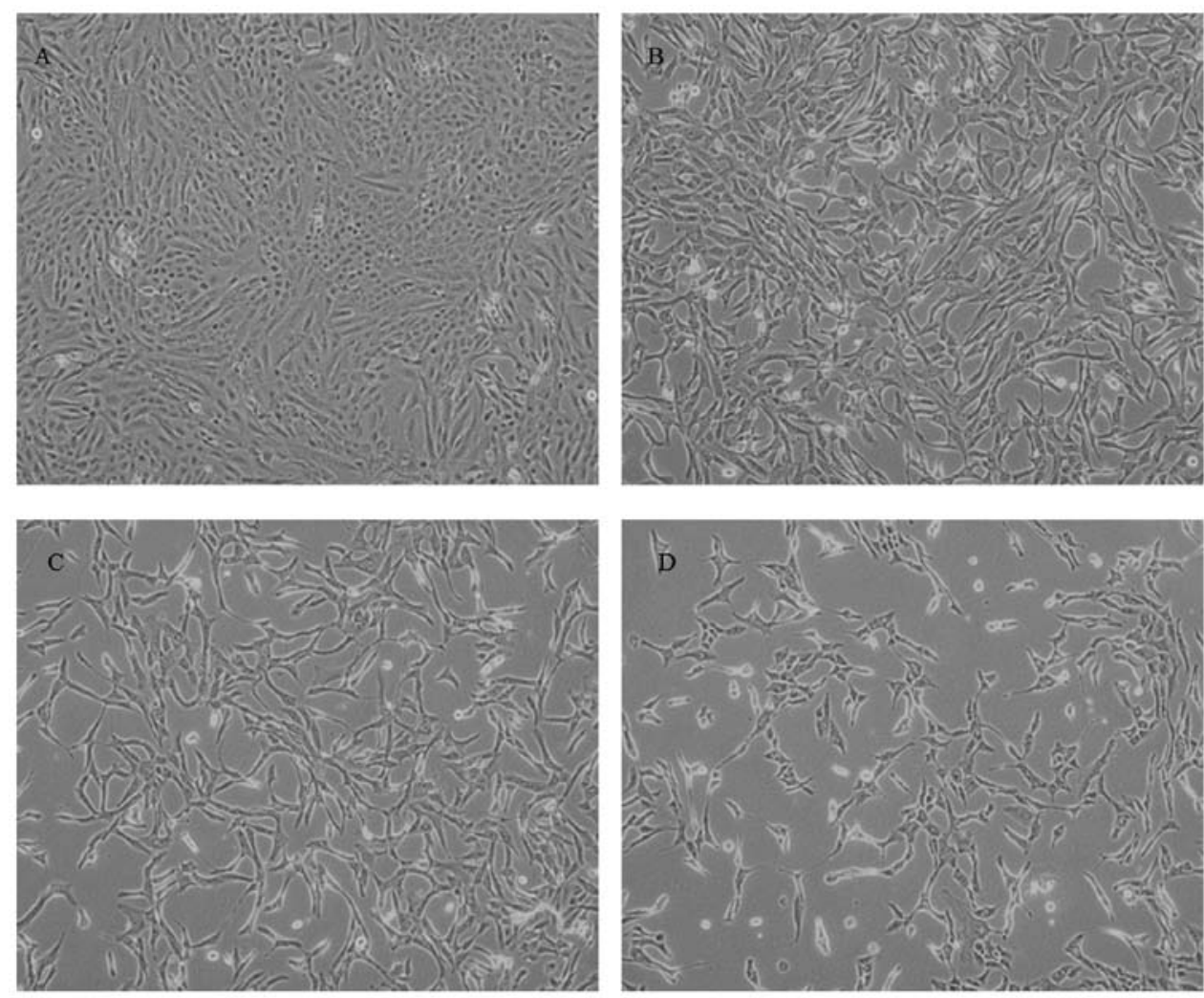

Figure 1. Effect of PHVO on the morphology of SW1353 cells. (A) Untreated control SW1353 cells. (B-D) SW1353 cells were treated with 50, 100, $150 \mu \mathrm{g} / \mathrm{ml}$ $\mathrm{PHVO}$ for $48 \mathrm{~h}$. Morphological changes of SW1353 cells were observed under a phase-contrast microscope. Images were taken at a magnification of x100.

shown in Fig. 1, PHVO treatment significantly reduced the cell density compared with the untreated control cells. The effect of PHVO on the viability of SW1353 cells was determined by MTT assay. As shown in Fig. 2, PHVO treatment decreased the cell viability in a dose- and time-dependent manner compared to the untreated control cells $(\mathrm{P}<0.05)$. Taken together, these data demonstrate that PHVO inhibits the proliferation of SW1353 cells.
PHVO blocks the progression of SW1353 cells from the G1 to the S phase. In order to examine the effect of PHVO treatment on the progression of SW1353 cells from the G1 to the $\mathrm{S}$ phase, we performed flow cytometric analysis of the SW1353 cells treated with 50, 100 and $150 \mu \mathrm{g} / \mathrm{ml}$ PHVO for $48 \mathrm{~h}$. As shown in Fig. 3, the treatment of SW1353 cells with PHVO led to a decrease in the number of cells in the $\mathrm{S}$ phase, associated with a concomitant increase in the number of cells 

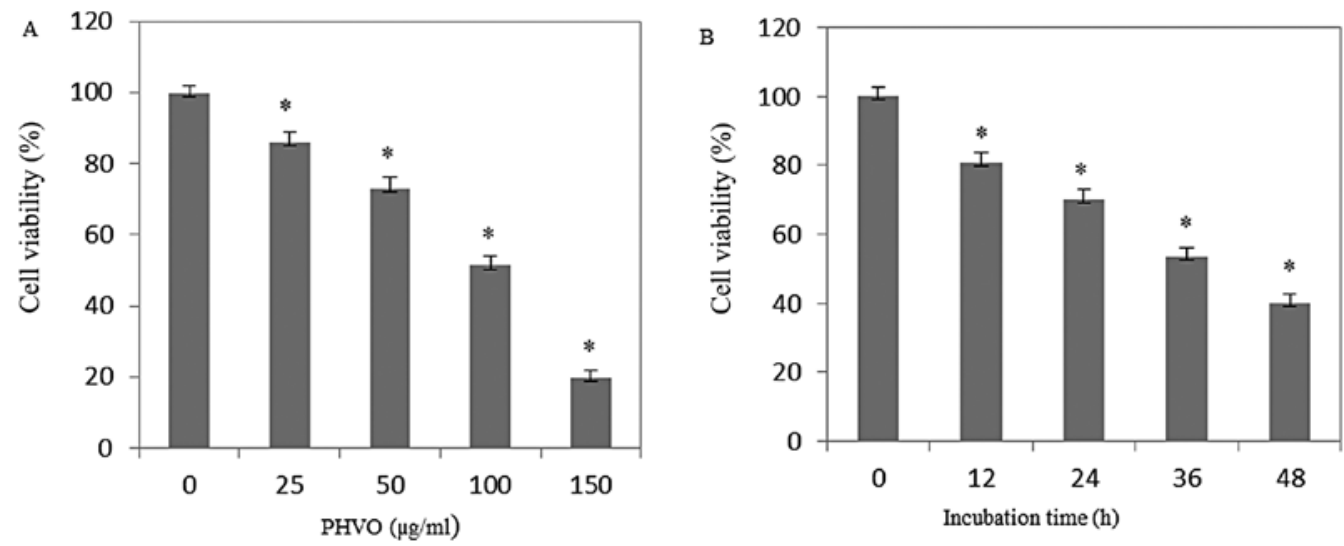

Figure 2. Effect of PHVO on SW1353 cell viability (A) SW1353 cells were treated with the indicated concentrations of PHVO for $48 \mathrm{~h}$. (B) SW1353 cells were treated with $100 \mu \mathrm{g} / \mathrm{ml}$ of PHVO for 12, 24, 36 and $48 \mathrm{~h}$. SW1353 cell viability was determined by MTT assay. The data were normalized to the viability of the untreated cells $(100 \%)$. Data are the means \pm SD (error bars). ${ }^{*} \mathrm{P}<0.05$, statistically significant vs. untreated cells.

A
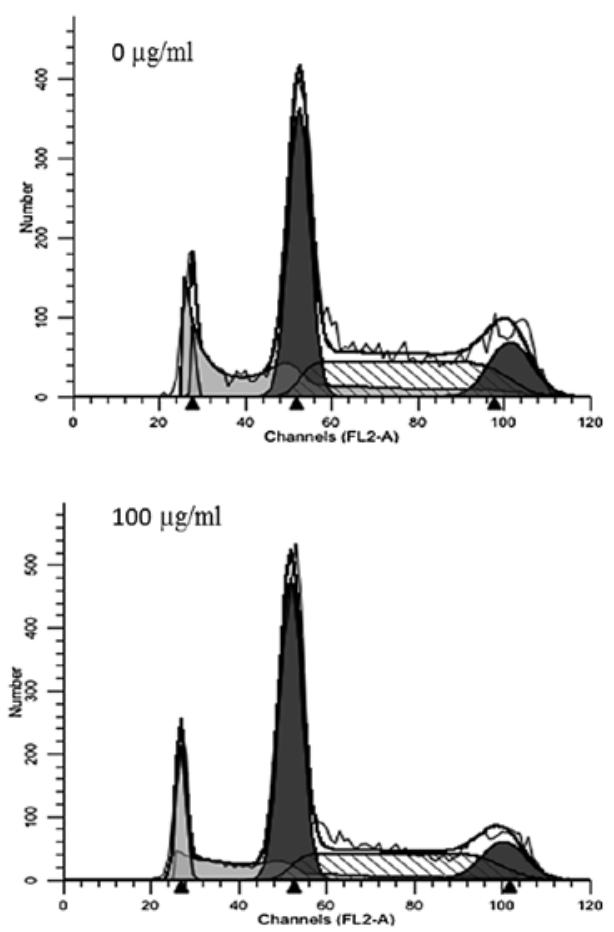

B

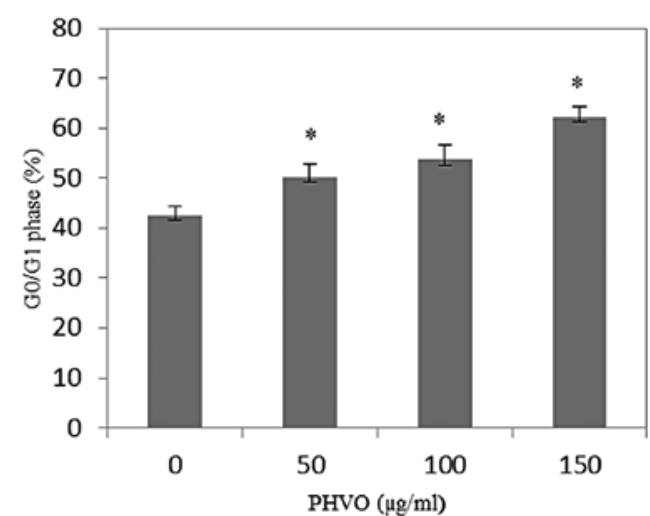

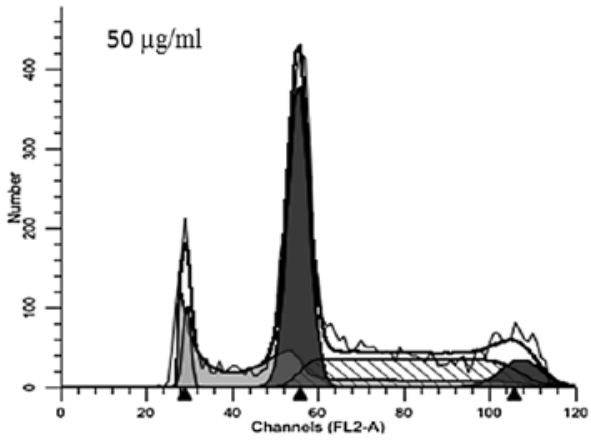
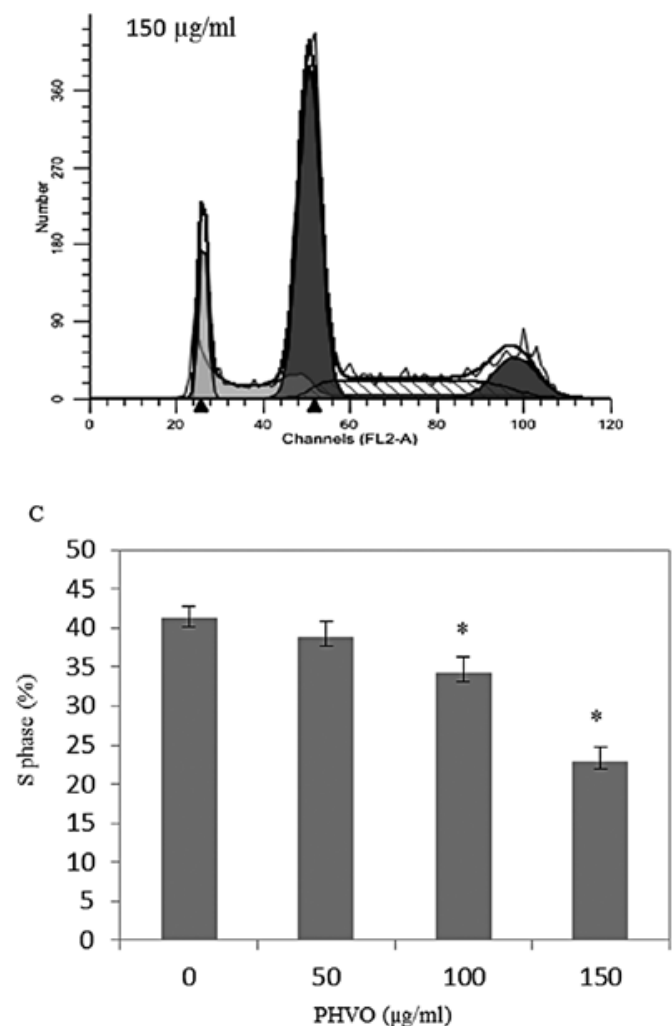

Figure 3. Effect of PHVO on the cell cycle progression of SW1353 cells. (A) SW1353 cells were treated with the indicated concentrations of PHVO for $48 \mathrm{~h}$, stained with PI and analyzed by FACS. (B) Percentage of SW1353 cells in the G0/G1phase after treatment with PHVO. (C) Percentage of SW1353 cells in $\mathrm{S}$ phase after treatment with PHVO. The data shown are the means $\pm \mathrm{SD}$ (error bars) from three independent experiments. ${ }^{*} \mathrm{P}<0.05 \mathrm{vs}$. control cells. 

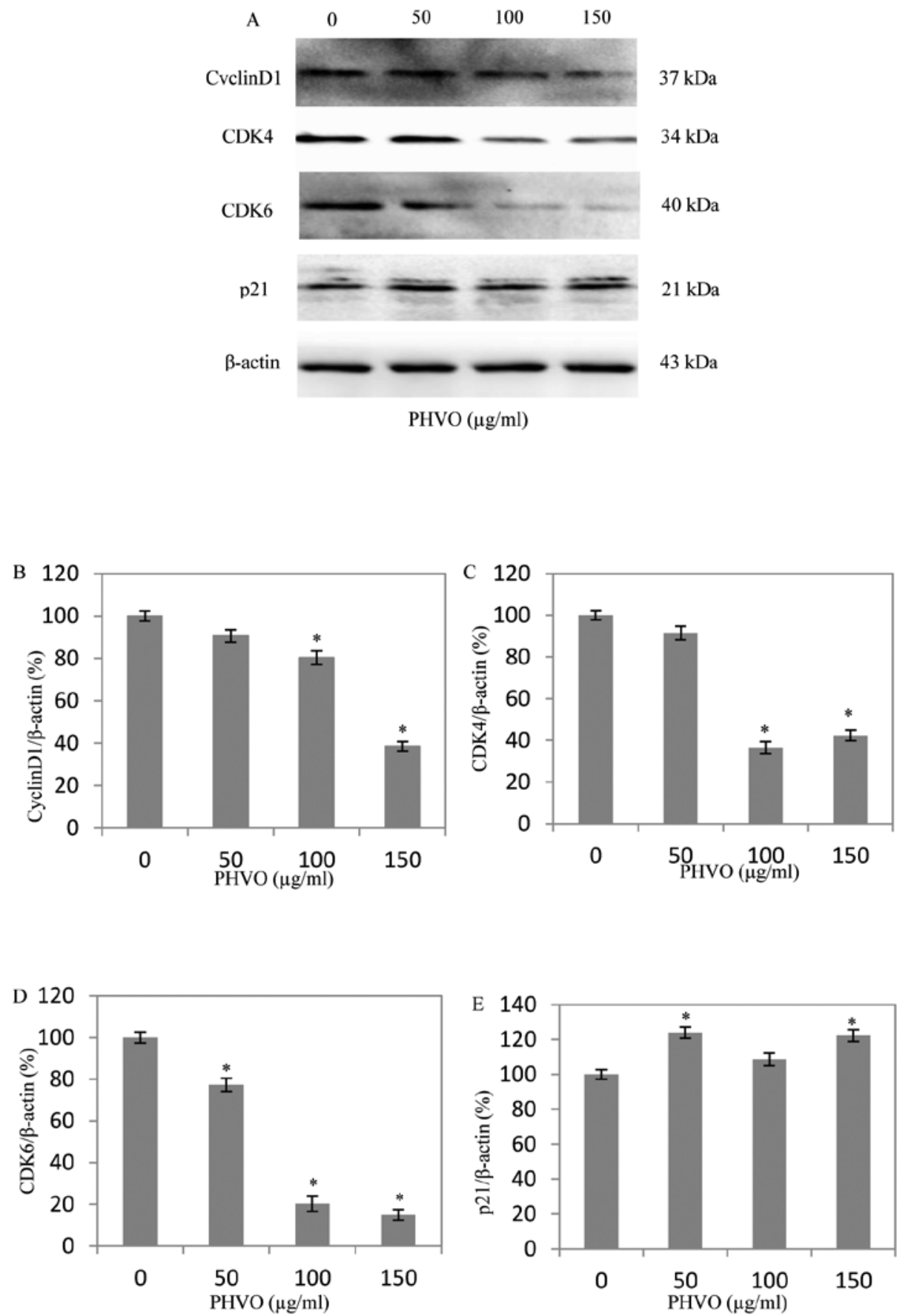

Figure 4. Effect of PHVO treatment on the protein expression levels of cyclin D1, CDK4, CDK6 and p21 in SW1353 cells. (A) SW1353 cells were treated with the indicated concentrations of PHVO for $48 \mathrm{~h}$. The protein expression levels of cyclin D1, CDK4, CDK6 and p21 were determined by western blot analysis. $\beta$-actin was used as the internal control. (B-E) Densitometric analysis. The data were normalized to the mean protein expression of the untreated controls $(100 \%)$. ${ }^{*} \mathrm{P}<0.05$ vs. controls.

in the G1 phase compared to the untreated cells $(\mathrm{P}<0.05)$. These results suggest that PHVO exerts growth inhibibitory effects on SW1353 cells by leading to cell cycle arrest at the G1 phase, and thus not allowing the cells to progress further in the cell cycle and proliferate.

PHVO regulates protein expression of cyclin D1,CDK4,CDK6 and $p 21$. To further investigate the mechanism behind the antiproliferative activities of PHVO, we performed western blot analysis to detect the protein expression of cyclin D1, CDK4,
CDK6 and p21 in the PHVO-treated SW1353 cells. The results showed that PHVO treatment decreased the expression of cyclin D1, CDK4 and CDK6 in dose-dependent manner, but increased that of p21 in the SW1353 cells (Fig. 4).

\section{Discussion}

Chondrosarcoma is the most common primary bone tumor and the second highest cause of cancer-related mortality in the pediatric age group. To date, surgery and adjuvant chemo- 
therapy are the main therapeutic approaches for patients with osteosarcoma, leading to extensive side-effects and multidrug resistance. Thus, the prognosis of osteosarcoma after surgery is poor (27-29). Therefore, the ultimate goal remains to discover effective agents, which are affordable and have minimal toxicity. In this study, the volatile components from Pyrolae herba were extracted by hydrodistillation and analyzed by GC-MS. The results showed the presence of a wide range of compounds in the volatile oil of Pyrolae herba, including terpenoids, aromatics, long-chain hydrocarbons, alcohols, ketones, acids and esters. Twelve components were identified representing $81.62 \%$ of the total integrated chromatographic peaks. Terpenoids and acids constitute more than $58 \%$ of the Pyrolae herba volatile oil, with n-hexadecanoic acid (29.29\%) and cedrol (17.08\%) as the major components.

In the present study, we investigated the antitumor activity of PHVO. MTT assay was used to evaluate the effects of PHVO on SW1353 cell viability. The results showed that PHVO was effective in inhibiting the proliferation of SW1353 cells.

Cell proliferation is primarily governed by the cell cycle (30). The G1/S transition is one of the two main checkpoints of the cell cycle (31), which is responsible for initiation and completion of DNA replication. In addition, cell cycle progression is also a tightly controlled event regulated positively by main cyclin-dependent kinases (CDK4/CDK6) and their cyclin-regulatory subunits (cyclin D1). Cyclin D1 is a positive regulator which binds to $\mathrm{CDK} 4$ or CDK6 to control cell cycle progression from the $\mathrm{G} 1$ to the $\mathrm{S}$ phase (32). An unchecked or hyperactivated cyclin D1/CDK4 complex often leads to uncontrolled cell division and malignancy (33-35). p21, the first identified inhibitor of cyclin/CDK complexes, was independently isolated as a CDK-binding protein (36). The main role of p21 in the cell cycle regulation is performed by inhibiting the activity of cyclin-CDK complexes $(37,38)$. G1 phase lengthening and $\mathrm{S}$ phase shortening could lead to cell cycle arrest and eventually to the inhibition of cell proliferation. In this study, cell cycle distribution was examined by flow cytometry. The results demonstrated that $\mathrm{PHVO}$ significantly increased the cell population in the G0/G1 phase and reduced that in the S phase. Furthermore, the expression of cell cycle regulating proteins (cyclin D1, CDK4, CDK6 and p21) was detected by western blot analysis. The results demonstrated that PHVO treatment led to the downregulation of cyclin D1, CDK4 and CDK6 and the upregulation of $\mathrm{p} 21$. It was suggested that the molecular mechanism behind the PHVO inhibition of SW1353 cell proliferation was cell cycle arrest at the G1/S phase.

The results of this study demonstrate that the volatile oil of Pyrolae herba significantly inhibits the growth of SW1353 cells. Nevertheless, volatile oil is a complex combination of a variety of chemical components, any of which may play a role in inhibiting cell growth. It is not clear as to which of the components contribute most significantly to antitumor activity. Therefore, components of volatile oil from Pyrolae herba should be further investigated in order to elucidate the individual antitumor activity of each component. The antitumor activity of the mixture was then compared with the expected antitumor activity calculated by the sum of efficiencies of each compound separately, relative to their proportions in the mixture. If it was higher, a synergy was pointed out, whereas a lower value was representative of an antagonism. In so doing, it may be helpful to discover more effective antitumor compounds from the volatile oil of Pyrolae herba.

In conclusion, the direct application of volatile oil in the treatment of chondrosarcoma has thus far not been considered. However, the presence of potential antitumor compounds in the volatile oil from Pyrolae herba, as well as the low toxicity of the oil at rather low doses may provide possibilities for further investigations in the field of antitumor compounds.

\section{Acknowledgements}

This study was sponsored by the National Natural Science Foundation of China (no. 81072826), the Natural Science Foundation of Fujian Province (no. 2010Y0032) and the Chen Keji Integrative Medicine Developmental Foundation (no. CKJ2011003).

\section{References}

1. Cormier JN and Pollock RE: Soft tissue sarcomas. CA Cancer J Clin 54: 94-109, 2004.

2. Heare T, Hensley MA and Dell'Orfano S: Bone tumors: osteosarcoma and Ewing's sarcoma. Curr Opin Pediatr 21: 365-372, 2009.

3. Tan ML, Choong PF and Dass CR: Osteosarcoma: conventional treatment vs. gene therapy. Cancer Biol Ther 8: 106-117, 2009.

4. Gorlick R and Khanna C: Osteosarcoma. J Bone Miner Res 25: 683-691, 2010

5. Gordaliza M: Natural products as leads to anticancer drugs. Clin Transl Oncol 9: 767-776, 2007.

6. Ji HF, Li XJ and Zhang HY: Natural products and drug discovery. EMBO Rep 10: 194-200, 2009.

7. Zhao J, Jiang P and Zhang WD: Molecular networks for the study of TCM pharmacology. Brief Bioinform 11: 417-430, 2009.

8. Rocha AB, Lopes RM and Schwartsmann G: Natural products in anticancer therapy. Curr Opin Pharmacol 1: 364-369, 2001.

9. Cragg GM, Newman DJ and Snader KM: Natural products in drug discovery and development. J Nat Prod 60: 52-60, 1997.

10. Tu YY: The discovery of artemisinin (qinghaosu) and gifts from Chinese medicine. Nat Med 17: 1217-1220, 2001.

11. Nobili S, Lippi D, Witort E, Donnini M, Bausi L, Mini E and Capaccioli S: Natural compounds for cancer treatment and prevention. Pharmacol Res 59: 365-378, 2009.

12. Singh HP, Mittal S, Kaur S, Batish DR and Kohli RK: Chemical composition and antioxidant activity of essential oil from residues of Artemisia scoparia. Food Chemistry 114: 642-645, 2009.

13. Stanko KC, Orlić S, Politeo O, Strikić F, Kolak I, Milos M and Satovic Z: Composition and antibacterial activities of essential oils of seven Ocimum taxa. Food Chemistry 119: 196-201, 2010.

14. Chinese Pharmacopoeia Commission: Pharmacopoeia of the People's Republic of China. 1st edition. Chemical Industry Press, pp226-277, 2005.

15. Lee MH, Lee JM, Jun SH, et al: The anti-inflammatory effects of Pyrolae herba extract through the inhibition of the expression of inducible nitric oxide synthase (iNOS) and NO production. J Ethnopharmacol 112: 49-54, 2007.

16. Lee SM, An RB, Min BS, Na MK, Lee CH, Kang SJ, Maeng HY and Bae KH: A new naphthoquinone from Pyrola japonica. Arch Pharm Res 24: 522-523, 2001.

17. Galván IJ, Rashed NM, Jessulat M, et al: Antifungal and antioxidant activities of the phytomedicine pipsissewa, Chimaphila umbellata. Phy tochemistry 69: 738-746, 2008.

18. Kim SJ, Um JY and Lee JY: Anti-inflammatory activity of hyperoside through the suppression of nuclear factor- $\kappa \mathrm{B}$ activation in mouse peritoneal macrophages. Am J Chin Med 39: 171-174, 2011.

19. Nikolaev SM, Nikolaeva IG, Razuvaeva YG and Dorzhiew AM: Antioxidant activity and flavonoid composition of the new pancreoprotective preparation Pancreophyt. Pharm Chem J 45: 279-281, 2011.

20. Tsai SJ and Yin MC: Antioxidative and anti-inflammatory protection of oleanolic acid and ursolic acid in PC12 cells. J Food Sci 73: H174-H178, 2008. 
21. Ramos AA, Wilson CP and Collins AR: Protective effects of ursolic acid and luteolin against oxidative DNA damage include enhancement of DNA repair in Caco-2 cells. Mutat Res 692: 6-11, 2010

22. Wang JS, Ren TN and Xi T: Ursolic acid induces apoptosis by suppressing the expression of FoxM1 in MCF-7 human breast cancer cells. Med Oncol 29: 10-15, 2012.

23. Limami Y, Pinon A, Leger DY, Mousseau Y, Moreau JC, Beneytout JL, Delage C, Liagre B and Simon A: HT-29 colorectal cancer cells undergoing apoptosis overexpress COX-2 to delay ursolic acid-induced cell death. Biochimie 93: 749-757, 2011.

24. Huang CY, Lin CY, Tsai CW and Yin MC: Inhibition of cell proliferation, invasion and migration by ursolic acid in human lung cancer cell lines. Toxicol in Vitro 25: 1274-1280, 2011.

25. Shan JZ, Xuan YY, Ruan SQ and Sun M: Proliferationinhibiting and apoptosis-inducing effects of ursolic acid and oleanolic acid on multi-drug resistance cancer cells in vitro. Chin J Integr Med 17: 607-611, 2011.

26. Chinese Pharmacopoeia Commission: Pharmacopoeia of the People's Republic of China. Chemical Industry Press, pp64-65, 2000

27. Bacci G, Ferrari S, Bertoni F, Ruggieri P, Picci P, Longhi A, Casadei R, Fabbri N, Forni C, Versari M and Campanacci M Long-term outcome for patients with nonmetastatic osteosarcoma of the extremity treated at the istituto ortopedico rizzoli according to the istituto ortopedico rizzoli/osteosarcoma-2 protocol: an updated report. J Clin Oncol 18: 4016-4027, 2000

28. Stefano F and Emanuela P: Adjuvant and neoadjuvant combination chemotherapy for osteogenic sarcoma. Curr Opin Oncol 19: 341-346, 2007.
29. Lamoureux F, Trichet V, Chipoy C, Blanchard F, Gouin F and Redini F: Recent advances in the management of osteosarcoma and forthcoming therapeutic strategies. Expert Rev Anticancer Ther 7: 169-181, 2007.

30. Sherr CJ: Cancer cell cycles. Science 274: 1672-1677, 1996.

31. Nurse P: Ordering $S$ phase and $M$ phase in the cell cycle. Cell 79: 547-550, 1994.

32. Zhang M, Xie R, Hou W, Wang B, Shen R, Wang X, Wang Q, Zhu T, Jonason JH and Chen D: PTHrP prevents chondrocyte premature hypertrophy by inducing cyclin-D1-dependent Runx2 and Runx3 phosphorylation, ubiquitylation and proteasomal degradation. J Cell Sci 122: 1382-1389, 2009.

33. Haraken S, Abu-EI-Ardat K, Diab-Assaf M, Niedzwiecki A, EI-Sabban M and Rath M: Epigallocatechin-3-gallate induces apoptosis and cell cycle arrest in HTLV-1-positive and -negative leukemia cells. Med Oncol 25: 30-39, 2008.

34. Kessel D and Luo Y: Cells in cryptophycin-induced cell-cycle arrest are susceptile to apoptosis. Cancer Lett 151: 25-29, 2000.

35. Zafonte BT, Hulit J, Amanatullah DF, Albanese C, Wang CG, Rosen E, Reutens A, Sparano JA, Lisanti MP and Pestell RG: Cell-cycle dysregulation in breast cancer: breast cancer therapies targeting the cell cycle. Front Biosci 5: d938-d961, 2000.

36. Harper JW, Adami GR, Wei N, Keyomarsi K and Elledge SJ: The p21 Cdk-interacting protein Cip1 is a potent inhibitor of G1 cyclin-dependent kinases. Cell 75: 805-816, 1993.

37. Chen JJ, Jackson PK, Kirschner MW and Dutta A: Separate domains of p21 involved in the inhibition of Cdk kinase and PCNA. Nature 374: 386-388, 1994.

38. Goubin F and Ducommun B: Identification of binding domains on the p21Cip1 cyclin-dependent kinase inhibitor. Oncogene 10: 2281-2287, 1995. 